\title{
Seasonal Abundance of Peach Fruit Fly (PFF), Bactrocera zonata Saund., and Mediterranean Fruit fly (MFF), Ceratitis capitata Wied., (Tephritidae - Diptera) on Varieties of Different Grapes, in Giza Gov. Egypt Afia, Y. E. \\ Plant Protection Research Institute, Dokki - Giza - Egypt
}

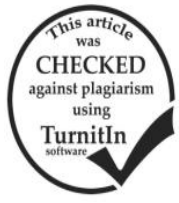

\section{ABSTRACT}

Relative abundance of tested pests, peach fruit fly (PFF), Bactrocera zonata Saunder, and Mediterranean fruit fly (MFF), Ceratitis capitata Wiedemann, on coloured grapes varieties, Red grape (Crimson), Black grape (Autumn royal) and white grape (Early sweet), were searched throughout the seasons 2014 to 2016, beginning first March to first November as a catch/trap/males day at Khatatiba district in Giza Governorate. The total captured males of both fruit flies throughout the three seasons in three grapes varieties is (1481.85 males) distributed descendingly as follows: (287.53, 400.23 and 794.53 male) representing $(19.37,27.01$ and $53.62 \%)$ in first, second and third seasons, respectively. Also the white grapes (early sweet) come as the superior one with total number of ( 889.5 male) amounting $60 \%$ of whole total capture. Red grape (crimson) and black grape (autumn royal) varieties come in the second and third order with total capture (411.84and 180.81 males) respectively, amounting 27.79 and $12.21 \%$ of the whole total males captured through three season, respectively comparing the relative abundance of MFF and PFF in each variety throughout the three seasons indicated, both species had the same trend in the three seasons all over the tree verities and the rate of replacement by MFF over PFF was prononeed at early sweet where the population ratio of MFF to PFF were $(94.07,81.51$ and $71.67 \%)$ to $(5.93,18.49$ and $28.33 \%)$ during the third, second and first seasons, respectively. While the lowest one observed in crimson variety, where were (64.947.43 and 38.57) to (38.09, 52.57 and 61.43) during the third, second and first seasons, respectively. The total monthly of both fruit flies recorded two peaks on different grapes varieties through period from May to September during three successive seasons. The first and highest peak occurred in May with total monthly catch of $64.29,112.66$ and 345.09 males/month representing $22.39,28.15$ and $43.44 \%$ from total population, respectively. while the second and lowest one recording on September with total of $80.53,87.21$ and 66.5 males/month representing $28.05,21.79$ and $8.37 \%$ from total population during first, second and three seasons, respectively. Statistical analysis for the relationship between population of both fruit flies and prevailing climatic factors, the simple correlation out 27 cases 7 revelled significance correlations of out which 4 and 3 cases for PFF and MFF were positively significant, respectively. This cases distributed in early sweet and crimson variety only while autumn royal variety were non-significant. Weather factors efficacy on the fruit flies showed no significant during period activity of tested pest. Effect of studied fruit age on the population density of fruit showed no significant during period activity of tested pests on all varieties also, both physiological and biological factors of fruits flies as well as the maturity states of the three varieties of grapes play an integral role in environmental factor with presence of the in the pests in Giza Governorate.

\section{INTRODUCTION}

The Grapevine, Vitis vinifera L., in Mediterranean region is a very important crop represented more than $40 \%$ for production in regions of Mediterranean countries; Spain, France and Italy as a main producers (FAO http://faostat.org/). This crop Grapevine,(Vitis spp.) considered the oldest fruit known and cultivated in Egypt. This crop cultivated in Governorates; Gharpya,, Behera , Munofya ,Sharqya and newly areas of reclaimed lands at fayoum , Mania, and Assiut Governorates, and used in many ways as follows; consumed fresh, raisin and seedless drying, fresh juice, fermented and export and the cultivated area about $20 \%$ from the all cultivated area.

White \&Elson-Harries, 1994, reported that, Family Tephritidae, true flies of fruit, includes about $4000 \mathrm{spp} / 500$ genera, such as, Diptera one of most important economic, and the larvae attack the most of soft fruits for the commercial fruits, also females lay eggs inside fruits, then hatching maggots devour into pulp, caused, contaminated by fungal and bacterial diseases. More than 1500 species in the world wide, 50 of which represented major pests and 30 are economic pastes. Liquido et al., 1991, mentioned that, the $C$. capitata, the most species attacks more than 350 host plants in the world.

Some authors were reported around Mediterranean fruit fly as a potential pest attacks grapevines in California, Brazil, Chile, South Africa, Venezula, Italy, Greece, Tunisina and Isreal (Swart et al .,1976; Autter.1977; Castro 1982; Elhanan \&Roessler ,1992; Dhouibi \&Fellah 1997; Buonocore et al .,1999; Barnes et al.,2006 and Roditakis et al. (2008). In Italy and South Africa, the sudden outbreaks were reported by, Buonocore et al .,(1999) and Barnes et al.,(2006). Also the Natal fruit fly, ceratitis rosae Karsch has been reported, reported as a pest of grapevine

El Ghawawabi, 1928, in Egypt reported that, the true fruit flies were distributed in most of Egyptian Governorates and infested the several host fruits which are available during the year causing damage and economic losses in Egypt, this report is agree with, Awad, (1980), Saafan, 1986, Hakim, and Awad, (1987) Hashem et al (1987) and Mohamed, (1993). The peach fruit fly (PFF), Bactrocera zonata (Saund.) (Tephritidae - Diptera) in Egypt attacks wide range of fruit species, apple, guava, mango, figs, peach, apricot and citrus crops, and meny vegetable crops were attacks and causing economic losses, El-Minshawy et al., (1999). The species B. zonata and $C$. capitata, They are widely spread in Egypt and become an important scientific material of Egyptian authors, i.e. Hashem et al (2001), El-Gendy, (2002), Afia, (2007), Amin (2008) and El-Mahdy, (2009).

This work was carried out to study of $C$, capitata and $B$. zonata fluctuation on varieties of different grapes under the field conditions concerned with maximum and minimum temperature.

\section{MATERIALS AND METHODS}

Throughout of the three successive seasons (2014 to 2016) on basis of trap catches in three orchard cultivated with three varieties of coloured grapes; white grape (Early sweet), red grape (Crimson) and black grape (Autumn royal), were studied the fluctuation of peach fruit fly (PFF), Bactrocera zonata Saunder and Mediterranean fruit fly (MFF), Ceratitis capitata Wiedemann, concerned with relationship between activity of population and climatic conation in addition and the total monthly were studied. The fruit orchard (all at the fruiting stage) and cultivated in the same orchards'(10 feddan for each variety) with average 8-12 years old. Jackson traps (Harris et. al., 1971) as 30 units (15 traps for each fly) baited with mixture $4 \mathrm{ml}$ of (methyl eugenol 96\% \& trimedlure 96\% (attractant of male sex) + dichlorophose $10 \%$ (DDVP) a ratio of $8: 2$, for monitoring of PFF and MFF, were distributed randomly in a grape orchards. Five trap as replicates were used for each variety were injected again with the above mixture every 4- 
6 weeks and hanged for 18 weeks from March to November before and after fruiting of each varieties and placed inside the tree in the shaded side of the tree (at which insects are found) at 1.5-2 meters height according to maturity start and harvesting of each verity. The traps were investigated weekly and the catches were counted according to captured/trap/day (CTD)

Weather factors:

Weather factors effects on the population of both tested pests (MFF) and (PFF) were studied; day-maximum temperature (D. Max.T.), day-minimum temperature (D.Min.T.) and daily mean of relative humidity (D.M.R.H.). Data records for the tested weather factors of Giza Gov., were obtained from Central Lab. for Agric. Meteorology, Agric. Res. Canter. Daily records of each weather factor were grouped of means/weekly according to sampling dates, and the tested weather factors were considered over 18 weeks for each crop (i.e, early sweet, crimson and autumn royal) which included the ripping stage for each crop.

Statistical analysis:

The simple correlation and regression values were calculated to determine the relationship between the mean numbers of male flies captured per trap week and prevailing climatic conditions. The partial regression analyses were calculated to determine the effect of each weather factor alone. In addition, analysis of variance ( $F$ test) and amount of variability in population density could be accounted by the tested weather factors combined (explained variance percent, i.e, E.V. \%) were estimated by applying

The "C. multipliers formula" as described by Fisher (1950). Ripping of the fruits during this period was presented as fruit age (X). These ripping stages were considered as biotic factor affecting the trapping of the flies. This variable was considered as nonlinear relation (polynomial of the fourth degree, $Y=a+b_{1} X+b_{2} X^{2}+b_{3} X^{3}+$ $\mathrm{b}_{4} \mathrm{X}^{4}$ ). The multiple regression analysis was used.

Data obtained were analysed by using ANOVA. Mean separation was conducted using L.S.D. in SAS program (SAS Institute, 1988).

\section{RESULTS AND DISCUSSION}

The seasonal activity of the tested pests, the peach fruit fly (PFF), Bactrocera zonata Saunder and Mediterranean fruit fly (MFF), Ceratitis capitata Wiedemann were searched for three successive seasons (2014 to 2016) starting from March to November on three varieties of different coloured grapes.

First season 2014:

Data present in (Fig. 1) indicated that, the fluctuation for (PFF), were started earlier three weeks at begging of March in early sweet variety with high numbers 2.8 flies because of presence of flies from the previous host as Valencia orange, Peach and Apricot which were harvested previously, while low numbers (1.054) for (MFF), appeared lately at April beginning. These low numbers were attributed with the beginning of the variety ripping period. Both species population were raised gradually to reach the highest peak on the $20^{\text {th }}$ of May and $3^{\text {th }}$ of June with high mean numbers 18.65 and 7.4 flies for (MFF) and (PFF). These increase may be due to the suitable weather factors especially means of minimum, maximum temperature which were (17.6 \& $\left.33.29^{\circ} \mathrm{C}\right)$ and $\left(21.3 \& 33.14{ }^{\circ} \mathrm{C}\right)$, respectively, also relative humidity of $60.9 \%$ and $54.8 \%$ and attributed with the complete ripping stage of fruit variety. The flies' population density was decreased gradually with the end of early sweet harvest. On the contrary the population density of flies on Crimson variety started earlier in begging of July with high numbers 1.2 flies for MFF coinciding with emigration of flies previous host early sweet which was harvested earlier, while allow numbers 0.2 flies for PFF appeared lately at Mid of July .The population density was increased gradually to record a peak for each species that represented by 10.52 and 20.27 flies for MFF and PFF on the $16^{\text {th }}$ and $2^{\text {nd }}$ of September, when the maximum and minimum temperature means were $(33.14 \& 34.53)$ and $\left(25.1 \& 24.9^{\circ} \mathrm{C}\right)$, respectively. as well as relative humidity of 77.5 and $69.95 \%$. This period of seasonal activity was coincided with the full ripping stage of variety and the highest temperature during the summer season. After harvesting population density was decreased gradually. On the other hand, same trend was occurred in Autumn royal variety, the first and highly incidence was occurred on the $6^{\text {th }}$ of May of 0.142 for MFF coinciding with emigration of flies previous host early sweet, peraim, filem grapes varieties which was at rapping stage, while allow numbers 0.2 flies for PFF appeared lately four weeks at begging of June, These low numbers were due to the inadequate the wither factor for incidence and activation for PFF .Then, the population gradually increased to make lowest peak which recorded on the $15^{\text {th }}$ and $29^{\text {th }}$ of June 5.73 and 3.6 flies for MFF and PFF at maximum and minimum temperature of $(34.43 \& 34.57)$ and $\left(22.6 \& 23.9^{\circ} \mathrm{C}\right)$, respectively and relative humidity of 68.9 and $67.1 \%$. After that the population decreased until the first of September and until end harvesting.
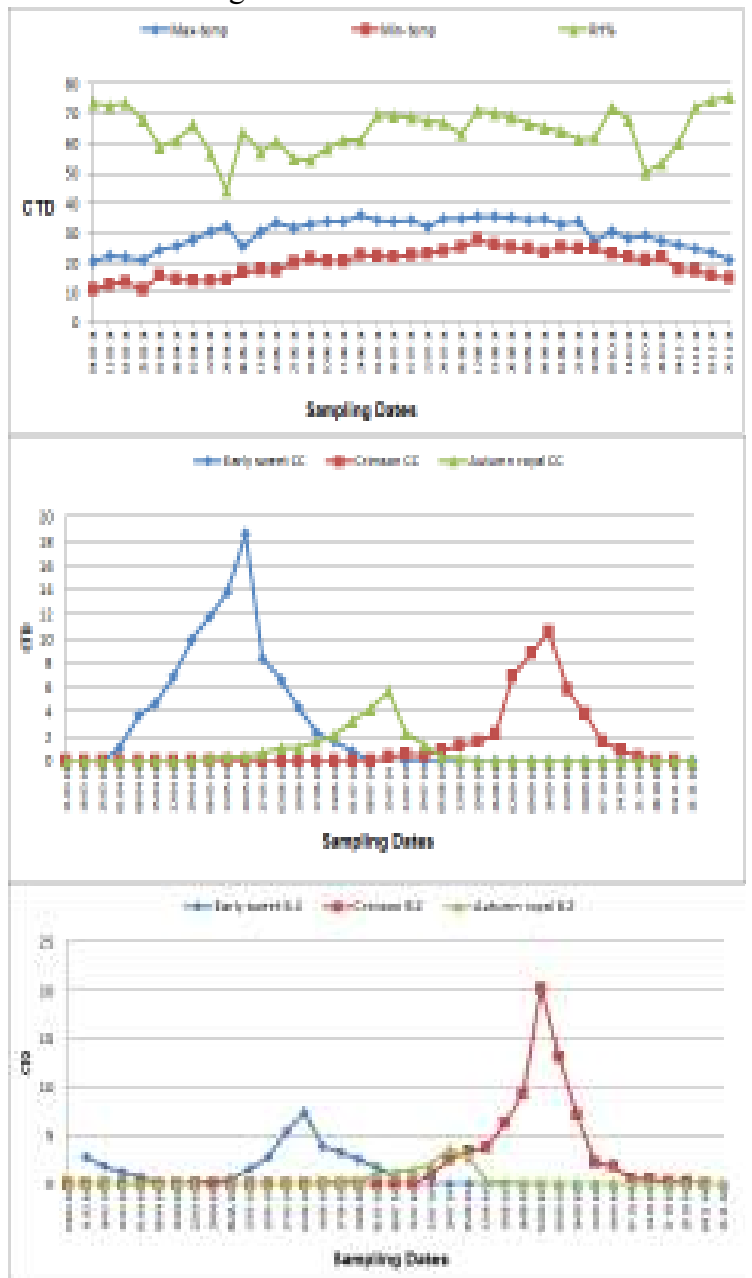

Fig. 1. Illustration (CTD) for males attracted of $C$. capitata and $B$. zonata on varieties of different grape concerned with weather factors in Khatatiba district, Giza Governorate in 2014 season. 
Second season (2015):

Data present in (Fig. 2) Reveal that the activity of PFF started earlier one weeks at beginning of March in early sweet variety with high numbers 1.8 flies, while allow numbers 1.4 for MFF appeared in Mid of March, Then decay occurs in population density of PFF for two weeks and stared increased once again ,while the population of MFF gradually elevated during the successive inspections season and formed single peak of seasonal abundance, recorded a CTD of 33.8 and 7.8 flies on the $12^{\text {th }}$ and $26^{\text {th }}$ of May for MFF and PFF, respectively. This raise might be due to the enhancement of weather conditions, especially the minimum and maximum temperature that was recorded ( 25 $\left.\& 20^{\circ} \mathrm{C}\right)$ and $\left(31.29 \& 34.75{ }^{\circ} \mathrm{C}\right)$, respectively, and the relative humidity of 65 and $53.35 \%$, also early sweet variety fruits developed in a complete ripping stage. The population gradually decreased to completely disappear on the end of early sweet variety harvesting. On the contrary the activity of MFF started earlier than PFF one weeks at Mid of March with 0.2 flies, on Crimson variety, then the population density of both flies was increased gradually to record a peak for each species that represented by 12.8 and 18.4 flies on the $15^{\text {th }}$ and $1^{\text {nd }}$ of September, when the minimum and maximum temperature means were $(23.4 \&$ $\left.24.9^{\circ} \mathrm{C}\right)$ and $(35.8 \& 34.6)$ respectively, after harvesting population density was decreased gradually. In Autumn royal variety Similar trend which occurred in first season early and highly incidence was occurred on the $5^{\text {th }}$ of May of 0.38 for MFF while allow numbers 0.2 flies for PFF appeared lately five weeks at begging of June .Then, the population gradually increased to make lowest peak which recorded on the $30^{\text {th }}$ and $17^{\text {th }}$ of June and July 8.6 and 3.8 flies for MFF and PFF at minimum and maximum temperature of $\left(24.3 \& 25.4^{\circ} \mathrm{C}\right)$ and $(34.29 \& 34.71)$, respectively and relative humidity of 62.2 and $68.50 \%$. After that the population decreased until the first of September and until end harvesting.

\section{Third season (2016):}

Data illustrated in (Fig. 3) Show that the population fluctuation of two fruit flies started at the same time on early sweet variety with relativity low number 1.8 and 1.2 flies for MFF and PFF on the $15^{\text {th }}$ of March. Then decay occurs in population density of PFF for three weeks and stared increased once again, while the population of MFF increased gradually formed single peak of seasonal abundance of 89.8 and 6.2 flies on the $10^{\text {th }}$ and $24^{\text {th }}$ of June for MFF and PFF, respectively. This raise might be due to the enhancement of weather conditions, especially the minimum and maximum temperature that was recorded $\left(24 \& 28^{\circ} \mathrm{C}\right)$ and $(39 \& 34.6)$ respectively, and the relative humidity of 46 and $45.5 \%$, also early sweet variety fruits developed in a complete ripping stage. The population gradually decreased to completely disappear on the end of early sweet variety harvesting.

Similar trend the population density of both flies started at the same time with relativity low number 0.4 and 0.24 flies for MFF and PFF on the $5^{\text {th }}$ of July on Crimson variety. Then the population density of both flies was increased gradually to record a peak for each species that represented by 16.8 and 8.4 flies on the $6^{\text {th }}$ and $23^{\text {nd }}$ of September and August, when the maximum and minimum temperature means were $(34.4 \& 33.7)$ and $\left(29 \& 30^{\circ} \mathrm{C}\right)$, respectively, and humidity were 54.5 and $56.5 \%$, respectively. This period was coinciding with improvement of weather conditions as well as full ripping stage of Crimson variety. The population gradually decreased to completely disappear on the end of Crimson variety harvesting. In autumn royal variety, similar trend which occurred in first and second seasons early incidence was occurred on the $3^{\text {th }}$ of
May of 0.2 for MFF while 0.2 flies for PFF appeared lately six weeks at mid of June. Then, the population gradually increased to make lowest peak which recorded on the $21^{\text {th }}$ and $5^{\text {th }}$ of June and July 15.6 and 2.2 flies for MFF and PFF, respectively at maximum and minimum temperature of (31.29 \& 36.9) and $\left(29{ }^{\circ} \mathrm{C}\right)$, respectively and relative humidity of 52.2 and $56 \%$, after that the population decreased until the first of September and until end harvesting
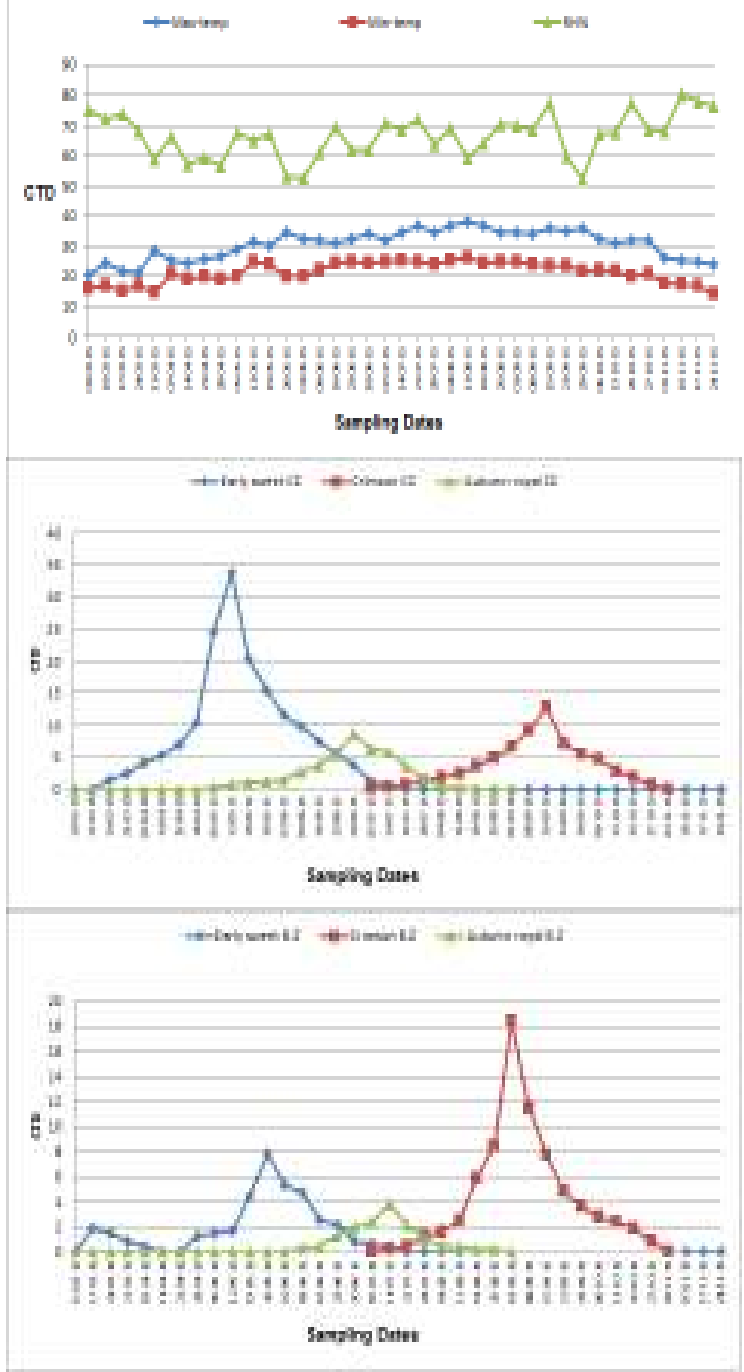

Fig. 2. Illustration (CTD) for males attracted of $C$. capitata and $B$. zonata on varieties of different grape concerned with weather factors in Khatatiba district, Giza Governorate in 2015 season.

These data obtained was agreement with Gupta et al. (1990) in India mentioned that, the captured males/traps of B. zonata in second week of April to second week of November, the populations of adult fly gave one peak during the maturation fruit in month of June. Agarwal and Kumar (1999) in India, reported that (CTD) of captured flies were 39.94 and 134.92 for B. dorsalis and B. zonata, respectively, during months of April and August 1997 year. Ishtiaq et al., (1999) in India, recorded that, the peak of population $B$. zonata, in winter crop occurred in September month, while, it was decreased in December. Khan et al. (2002), in Pakistan, reported that, the total number of adult captured of $B$. zonata, were highest in mango orchards occurred during July and August. Mohamed (2002) in Egypt, Sohag Gov., he mentioned that, the highest total catch of $B$. zonata occurred 
duroing August to October, while the captures during other months were very low numbers. Khan et al. (2003) noticed that the catch of B. zonata were the highest when using of pheromones in guava orchards in the late of August and first of September. Kawashita et al. (2004) in Srilanka, reported that, the methyl eugenol attractant were used for attracted of B. zonata during April to July. Khalid and Mishkatullah (2007), in Pakistan, showed that, population decreased during November to February, then increased during March to August when observed of $B$. zonata infestation in fruit fields, and the population gave one peak in July and August.
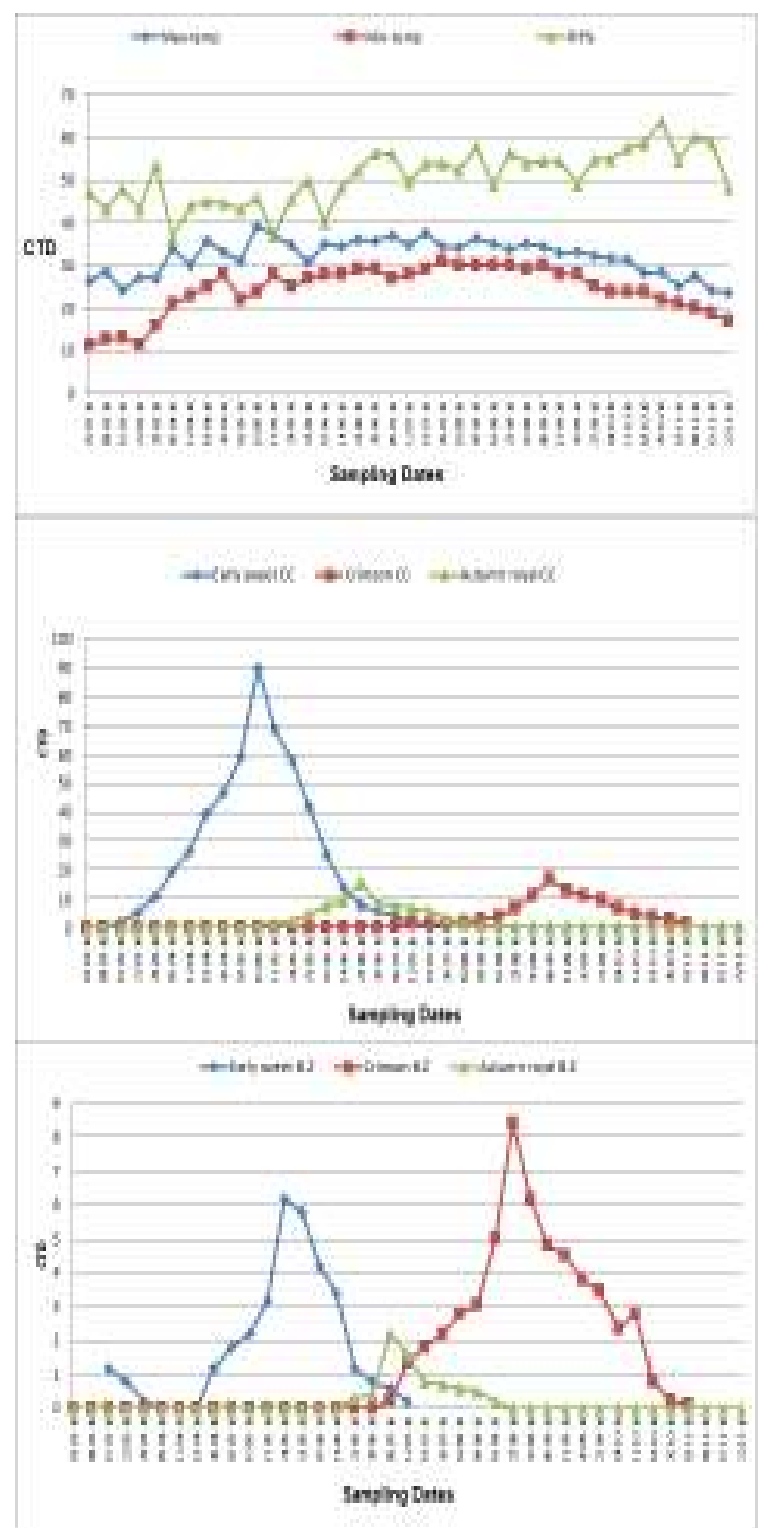

Fig. 3. Illustration (CTD) for males attracted of $C$. capitata and $B$. zonata on varieties of different grape concerned with weather factors in Khatatiba district, Giza Governorate in 2016 season.

Seasonal abundance/month of $B$. zonata and $C$. capitata on the three grape varieties:

Graphically cleared in (Fig. 4) reported that the total monthly density of population on March of successive inspected seasons a little number of males were captured, this is because of that (PFF) and (MFF) were over wintered during this months. The density of population rise gradually in consequent months to record the first and highest peak of seasonal abundance on May during the three seasons with total monthly catch of $64.29,112.66$ and 345.09 males/month representing $22.39,28.15$ and $43.44 \%$ from total population, respectively. This may be due to that white grapes variety more favorable to fruit flies than colored grapes verities also during this period coincides highly incidence of MFF which preferred the lower condition of weather factors than PFF. After that the population decreased until the end of August and increased again recording the second and lowest peak on September throughout the three seasons with total monthly catch of $80.53,87.21$ and 66.5 males/month representing $28.05,21.79$ and $8.37 \%$ from total population during first, second and three seasons, respectively. This attributed to full raping stage Crimson variety and highly incidence of PFF which preferred the wormer condition of weather factors than MFF.

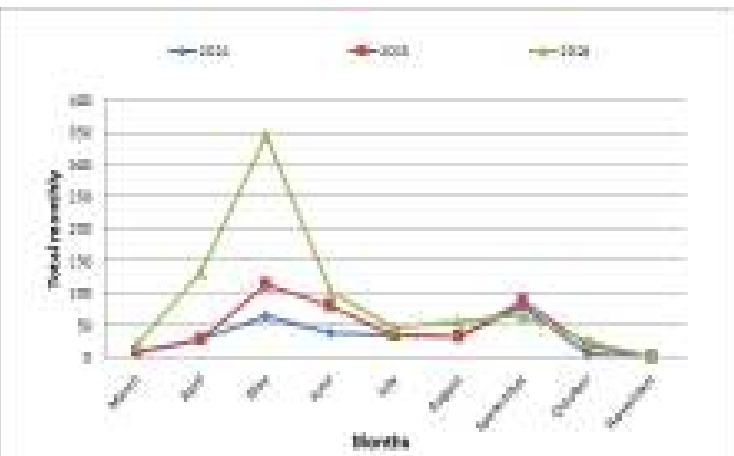

Fig. 4. The monthly catches fly/trap of $B$. zonata and $C$. capitata on three varieties of grapes in Giza Governorate during (2014 to 2016) concerned with temperature and relative humidity.

The results obtained are agreement with Khan et al. (2003), in India, he found that, the most active of population density of $B$. zonata mostly occurred during March to August. Saafan et al. (2000) reported that the fallen fig fruits produced $C$. capitata and B. zonata only during the period from September until November 1997 and 1998. Saafan (2005a\&b) and Amin (2008) in Fayoum Governorate, they reported that the PFF fly activity were observed obviously in higher numbers at summer and autumn seasons and disappeared at winter and spring seasons when fruit hosts were not available and low weather conditions dominated. Rajitha and Shashidhar (2006a), in Dharwad and Karnataka in India, he found that population density of B. zonata at a mango orchard, one and two peaks during $1^{\text {st }}$ and $2^{\text {nd }}$ seasons, respectively, during July 2003 to April 2004. ElMahdy (2009) in egypt, Qalyubiya Gov. he found that the total monthly catch recorded two peaks of seasonal activity, the first in July and the second in October (2004-2006) respectively. Afia (2007) demonstrate the population of PFF and MFF on the eight fruit host species over the three seasons 2000/2003 had (one, two or three) and (one, three or four) peaks activity in fayoum, Qalyubiya and Giza Governorates respectively, Khalid and Mishkatullah (2007) in Pakistan reported that the lowest catch number of B.zonata recorded during November to February, and increased gradually during March to August, and the peak of population occurred in July and August, and reduced in October depending on maturity of host fruit.

Grand total of both fruit flies $B$. zonata and $C$. capitata population in different three varieties of grape during the tree seasons

Results in Table (1) present the grand total captured males of both fruit flies throughout the three seasons in three grapes varieties, This grand total is (1481.85 males) 
distributed descendingly as follows: (287.53, 400.23 and 794.53 male) representing $(19.37,27.01$ and53.62 \%) in first, second and third seasons, respectively. Also data revealed that white grape (Early sweet) come as the superior one with total number of ( 889.5 male) amounting $6 . \%$ of whole total capture. Red grape (Crimson) and black grape (autumn royal) varieties come in the second and third order with total capture (411.84and 180.81 males) respectively, amounting 27.79 and $12.21 \%$ of the whole total males captured through three season, respectively.

Generally, comparing the relative abundance of MFF and PFF in each variety throughout the three seasons indicate, both species had the same trend in the three seasons all over the tree verities as shown in table (1) the rate of replacement by MFF over PFF was prononeed at early sweet where the population ratio of MFF to PFF were $(94.07,81.51$ and 71.67 $\%)$ to $(5.93,18.49$ and $28.33 \%)$ during the third, second and first seasons, respectively. Under Autumn royal variety, the rate of replacement was moderate, where it were (91.47, 74.87 and 63.25$)$ to $(8.53,25,13$ and 36.75$)$ during the third, second and first seasons. Under Crimson variety, the rate of replacement was the lowest, where were 64.947 .43 and $38.57)$ to $(38.09,52.57$ and 61.43$)$ during the third, second and first seasons, respectively. The results revealed that the percentage of MFF was higher than PFF during the third season and second and first, respectively, This results reverse all the researcher results which mentioned earlier from 2000 to 2010 in Egypt that population of PFF was more than MFF Afia (2007) indicated that the total captured males of PFF were higher than that of MFF in three Governorate throughout three seasons 2000/2003 refer to PFF population more adapted to tropical areas surpassed the population of MFF which more adapted to temperate areas also Amin (2008) reported that the mean monthly CTD of PFF was dominance over that of MFF in fayoum Governorate during $(2005 / 2007)$ this results in this research attributed to the state success through national program for eradication of PFF only from 2008/2016 and totally overlooked the presence of anther and oldest fruit fly MFF for that the population of MFF expected to increase during the coming year.

Table 1. General Total captured of males of B.zonata and C.capitata on three varieties on grapes in khatatba on Giza Governorate during three season(2014-2016).

\begin{tabular}{|c|c|c|c|c|c|c|c|c|c|c|c|}
\hline \multirow{3}{*}{ Years } & \multirow{2}{*}{\multicolumn{3}{|c|}{$\begin{array}{l}\text { White grape } \\
\text { Eearly sweet }\end{array}$}} & \multirow{2}{*}{\multicolumn{3}{|c|}{$\begin{array}{l}\text { Red grape } \\
\text { Crimson }\end{array}$}} & \multirow{2}{*}{\multicolumn{2}{|c|}{$\begin{array}{c}\text { Black grape } \\
\text { Autumn royal }\end{array}$}} & \multirow{3}{*}{$\begin{array}{l}\text { - Total of } \\
\text { - varieties }\end{array}$} & \multirow{3}{*}{$\begin{array}{l}\text { General } \\
\text { total }\end{array}$} & \multirow{3}{*}{ Percentage } \\
\hline & & & & & & & & & & & \\
\hline & total & perc & ntage & Total & Perc & ntage & total & percentage & & & \\
\hline 2014 & $131.13 \mathrm{c}$ & $\begin{array}{c}\text { C.C } \\
71.67\end{array}$ & $\begin{array}{c}\text { B. } \\
28.33\end{array}$ & $117.73 \mathrm{c}$ & $\begin{array}{l}\text { C.C } \\
38.57\end{array}$ & $\begin{array}{c}\text { B.Z } \\
61.43\end{array}$ & $38.23 \mathrm{c}$ & $\begin{array}{cc}\text { C.C } & \text { B.Z } \\
63.25 & 36.75\end{array}$ & 287.09 & & 19.37 \\
\hline 2015 & $201.93 \mathrm{~b}$ & 81.51 & 18.49 & $140.21 b$ & 47.43 & 52.57 & $58.092 b$ & $74.87 \quad 25.13$ & 400.23 & $\underset{5}{1481.8}$ & 27.01 \\
\hline 2016 & $556.14 \mathrm{a}$ & 94.07 & 5.93 & $153.9 \mathrm{a}$ & 64.9 & 38.09 & $84.49 \mathrm{a}$ & $91.47 \quad 8.53$ & 794.53 & & 5362 \\
\hline Total & 889.2 & & 00 & 411.84 & & .79 & 180.81 & 12.21 & & & 53.02 \\
\hline FFvalue & $606.04 * * *$ & - & 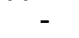 & $49.02 * * *$ & - & - & $131.5^{* * *}$ & - & & & \\
\hline LLSD at 0.05 & 10.117 & - & - & 9.025 & - & - & 7.023 & - & & & \\
\hline
\end{tabular}

Data presented in table (1) revelled that statistical analysis of variance showed high significant differences in the total No. of captured of both fruit flies flies among grapes varieties during three seasons classified according to time of maturation of each variety $\mathrm{F}=606.04),(\mathrm{F}=$ 49.02) \& $(\mathrm{F}=131.5)$ and L.S.D. at $0.05=(10.117),(9.025)$ and (7.023) for three varieties, respectively.

Results obtained in Table (2\&3) the relation between the climatic factors and PFF and MFF population density on different varieties during (2014/2016) most values not significant only significant relation will be discussed. For simple correlation out 27 cases 7 revelled significance correlations of out which 4 and 3 cases for PFF and MFF were positively significant, respectively. This cases distributed in Early sweet and Crimson variety only while Autumn royal variety were non-significant.

In Early sweet variety significantly relation appear between relative humanity and CTD number were $(\mathrm{r}=0.501)$ and $(\mathrm{r}=0.573)$ during third and first year for PFF and MFF respectively. The percentage of explained variance (E.V \%) were 25.06 and $32.83 \%$ for PFF and MFF, respectively. In

Table 2. Simple correlation and regression values between the weather factors and the ripping stage of the fruit in relation with capture males trap daily (CTD) of the peach fruit fly $B$. zonata on different grape varieties in Khatatba, Giza Governorate during 2014-2016 seasons

\begin{tabular}{|c|c|c|c|c|c|c|c|c|c|c|c|c|c|c|}
\hline \multirow[b]{2}{*}{ Varieties } & \multirow[b]{2}{*}{ Season } & \multicolumn{8}{|c|}{ Correlation values ( $\mathbf{r}$ ) } & \multicolumn{4}{|c|}{ Explained variance (E.V.\%) } & \multirow[b]{2}{*}{$\begin{array}{c}\text { Combined } \\
\text { effect } \\
\text { (E.V.\%) }\end{array}$} \\
\hline & & $\begin{array}{c}\text { Max. } \\
\text { Temp. } \\
\left.\text { ( }{ }^{\circ} \mathrm{C}\right)\end{array}$ & Prob. & $\begin{array}{c}\text { Min. } \\
\text { Temp. } \\
\left({ }^{\circ} \mathrm{C}\right)\end{array}$ & Prob. & $\begin{array}{c}\text { Average } \\
\text { Humidity } \\
(\%)\end{array}$ & Prob. & $\begin{array}{c}\text { Fruit } \\
\text { age }\end{array}$ & Prob. & $\begin{array}{c}\text { Max. } \\
\text { Temp. } \\
\left.\text { ( }{ }^{\circ} \mathrm{C}\right)\end{array}$ & $\begin{array}{c}\text { Min. } \\
\text { Temp. } \\
\left({ }^{\circ} \mathrm{C}\right)\end{array}$ & $\begin{array}{c}\text { Average } \\
\text { Humidity } \\
(\%)\end{array}$ & $\begin{array}{c}\text { Fruit } \\
\text { age }\end{array}$ & \\
\hline \multirow{3}{*}{$\begin{array}{l}\text { Early } \\
\text { sweet }\end{array}$} & 2014 & 0.339 & 0.168 & 0.414 & 0.088 & 0.171 & 0.497 & 0.357 & 0.146 & 11.51 & 17.13 & 2.94 & 12.76 & 19.30 \\
\hline & 2015 & 0.429 & 0.075 & 0.036 & 0.888 & 0.381 & 0.118 & 0.210 & 0.402 & 18.42 & 0.13 & 14.56 & 4.43 & 35.48 \\
\hline & 2016 & 0.396 & 0.104 & 0.381 & 0.118 & 0.501 & $0.034 *$ & 0.276 & 0.266 & 15.66 & 14.56 & $25.06^{*}$ & 7.64 & 46.18 \\
\hline \multirow{3}{*}{ Crimson } & 2014 & 0.510 & $0.031^{*}$ & 0.440 & 0.067 & 0.159 & 0.529 & 0.177 & 0.482 & $26.02 *$ & 19.38 & 2.52 & 3.13 & 0.464 \\
\hline & 2015 & 0.342 & 0.164 & 0.440 & 0.067 & 0.058 & 0.819 & 0.238 & 0.342 & 11.73 & 19.37 & 0.34 & 5.66 & $47.90^{*}$ \\
\hline & 2016 & 0.551 & $0.02 *$ & 0.641 & $0.004 *$ & 0.444 & 0.064 & -0.448 & 0.062 & $30.37 *$ & $41.08 *$ & 19.79 & 20.09 & $61.78^{*}$ \\
\hline \multirow{3}{*}{$\begin{array}{l}\text { Autumn } \\
\text { royal }\end{array}$} & 2014 & 0.177 & 0.480 & 0.283 & 0.255 & 0.444 & 0.064 & 0.374 & 0.126 & 3.16 & 8.03 & 19.77 & 14.01 & 26.29 \\
\hline & 2015 & 0.211 & 0.399 & 0.404 & 0.096 & 0.321 & 0.194 & 0.187 & 0.456 & 4.47 & 16.29 & 10.30 & 3.51 & 24.12 \\
\hline & 2016 & 0.126 & 0.618 & 0.036 & 0.885 & 0.367 & 0.134 & 0.124 & 0.621 & 1.59 & 0.13 & 13.47 & 1.56 & 17.53 \\
\hline
\end{tabular}

case of Crimson variety, significantly relation appear between maximum temperatures and CTD number $(\mathrm{r}=0.510)$ during first year and the percentage of explained variance (E.V.\%) was $26.02 \%$ for B. zonata only, while third season, the simple correlation between maximum and minimum temperatures and CTD number were $(r=0.551 \&$ $\mathrm{r}=0.641)$ and $(\mathrm{r}=0.460$ and $\mathrm{r}=0.517)$ and the percentage of explained variance (E.V.\%) were $30.37 \& 41.08 \%$ and 21.25 \& 26.77 for PFF and MFF, respectively. Data resented in Table (3\&4) added the effect of studied fruit age on the population density of fruit did not appear no significantly during the activity period of the pests on all varieties.

Data presented in Table $(2 \& 3)$ revealed that the combine effect of three weather factors and the fruit age were responsible of fruit flies activation on some varieties, on early sweet significantly percentage $60.24 \%$ appear in second season for MFF only, also significantly percentage were (47.90 and 51.33) for PFF and MFF during season, respectively and significant high significant( 61.78 and $72.00 \%$ ) for PFF and MFF. during third season, respectively 
Table 3. Simple correlation and regression values between the weather factors and the ripping stage of the fruit in relation with capture males trap daily(CTD) of Med fruit fly, C capitata (Wed) on different grape Varieties in Khatatba, Giza Governorate during 2014-2016 seasons

\begin{tabular}{|c|c|c|c|c|c|c|c|c|c|c|c|c|c|c|}
\hline \multirow[b]{2}{*}{ Varieties } & \multirow[b]{2}{*}{ Season } & \multicolumn{8}{|c|}{ Correlation values ( $\mathbf{r}$ ) } & \multicolumn{4}{|c|}{ Explained variance (E.V.\%) } & \multirow[b]{2}{*}{$\begin{array}{c}\text { Combined } \\
\text { effect } \\
\text { (E.V.\%) }\end{array}$} \\
\hline & & $\begin{array}{l}\text { Max. } \\
\text { Temp. } \\
\left({ }^{\circ} \mathrm{C}\right)\end{array}$ & Prob. & $\begin{array}{c}\text { Min. } \\
\text { Temp. } \\
\left({ }^{\circ} \mathrm{C}\right)\end{array}$ & Prob. & $\begin{array}{c}\text { Average } \\
\text { Humidity } \\
(\%)\end{array}$ & Prob. & $\begin{array}{c}\text { Fruit } \\
\text { age }\end{array}$ & Prob. & $\begin{array}{c}\text { Max. } \\
\text { Temp. } \\
\left({ }^{\circ} \mathrm{C}\right)\end{array}$ & $\begin{array}{c}\text { Min. } \\
\text { Temp. } \\
\left({ }^{\circ} \mathrm{C}\right)\end{array}$ & $\begin{array}{c}\text { Average } \\
\text { Humidity } \\
(\%)\end{array}$ & $\begin{array}{c}\text { Fruit } \\
\text { age }\end{array}$ & \\
\hline \multirow{3}{*}{$\begin{array}{l}\text { Early } \\
\text { sweet }\end{array}$} & 2014 & 0.197 & 0.432 & 0.010 & 0.968 & 0.573 & 0.0129 & 0.098 & 0.697 & 3.89 & 0.01 & $32.83 *$ & 0.97 & 39.76 \\
\hline & 2015 & 0.246 & 0.325 & 0.262 & 0.292 & -0.318 & 0.583 & 0.026 & 0.915 & 6.06 & 6.89 & 1.92 & 0.07 & $60.24 *$ \\
\hline & 2016 & 0.289 & 0.245 & 0.203 & 0.418 & -0.347 & 0.157 & -0.099 & 0.695 & 8.34 & 4.14 & 12.07 & 0.98 & 39.63 \\
\hline \multirow{3}{*}{ Crimson } & 2014 & 0.355 & 0.147 & 0.403 & 0.096 & 0.007 & 0.975 & -0.034 & 0.891 & 12.64 & 16.32 & 0.01 & 0.12 & 37.31 \\
\hline & 2015 & 0.340 & 0.167 & 0.242 & 0.331 & -0.341 & 0.165 & 0.018 & 0.942 & 11.58 & 5.90 & 11.69 & 0.03 & $51.33 *$ \\
\hline & 2016 & 0.460 & $0.054 *$ & 0.517 & $0.027 *$ & -0.410 & 0.090 & -0.271 & 0.276 & $21.25^{*}$ & $26.77 *$ & 16.83 & 7.36 & $72.00 * *$ \\
\hline \multirow{3}{*}{$\begin{array}{l}\text { Autumn } \\
\text { royal }\end{array}$} & 2014 & 0.125 & 0.391 & 0.003 & 0.990 & 0.239 & 0.337 & -0.015 & 0.952 & 4.62 & 0.0 & 5.76 & 0.2 & 44.38 \\
\hline & 2015 & 0.035 & 0.887 & 0.274 & 0.271 & 0.268 & 0.281 & 0.050 & 0.843 & 0.13 & 7.51 & 7.22 & 0.25 & 13.18 \\
\hline & 2016 & 0.029 & 0.907 & -0.073 & 0.771 & -0.009 & 0.969 & -0.376 & 0.123 & 0.09 & 5.5 & 0.1 & 14.19 & 46.59 \\
\hline
\end{tabular}

From the abovementioned discussion it could be stated that the changes population densities of PFF and MFF at the three grape varieties in Giza Governorate were mostly related to the simultaneous effects of the all factors selected (three weather factors, CTD and the ripping stage of the fruit than the single effect of each factor separately. The percentages of explained variance were highly significant or significant and non-significant during three seasons at the three grape varieties. The remaining unexplained variance were assumed to be due to the influence of other inconsiderable factors; biological, environ-mental, blooming and fruiting stages of the hosts and ripping stage of the fruit.

Data are agreement with Abu-Manzar and Srivastava (2004a), he reported that, the population density of $B$. zonata were significantly with min. temperature during 2002.The maximum and minimum relative humidity and rain was negatively and in significantly correlated during both years, except with minimum relative humidity and rain during 2003 in cue-lure and rain during 2003 in methyl. However Afia (2007) found that the weather factors were not the main driver for the population dynamics of both fruit files (PFF and MFF) in different corps at three Governorates Amin (2008) In Egypt found that the weather factors were apparent during periods of critical temperature, particularly during winter months in which population of $B$. zonata reduced to its minimal numbers. Also during summer months, the peach fruit fly was found to be adversely by such temperature increasing over optimal range $\left(30^{\circ} \mathrm{C}\right)$. Khalaf, et al., (2011) found that the number of pest was higher in 2010 compared to 2009, but the high temperature degree 45-51C in August 2010 caused decreasing the population density of Ceratitis capitata.

\section{REFERENCES}

Abu-Manzar, S. and J.P. Srivastava (2004a). Puter program to calculate life table parameters for an insect or mite species. Florida Entomolmgist ; 69 (4): 690-697.

Afia,Y.E. (2007). Comparative studies on the biology and ecology of the two fruit flies, in Egypt, Bacterocera zonata (Saunders) and Ceratitis capitata (Wiedemann). Ph.D. Thesis, Fac. Agric. Cairo. Univ. Egypt ; 301pp.

Agarwal , M. L. and P. Kumar (1999). Effect of weather parameters on population dynamics of peach fruit fly, Bacterocera zonata (Saunders).Entomol.;24(1):81-84.

Amin, A.A. (2008). Ecological and biological studies on the peach and Mediterranean fruit flies in Fayoum Governorate. Ph.D. Thesis, Fac. Agric. Fayoum Univ. Egypt, 255pp.

Autter, S.H (1977): Current fruit fly situation in Chile .FAO Plant Protection Bulletin 25, 118-119.

Awad , A.(1980): The possible genetic effect of certain mutagenic in the Mediterranean Fruit fly Ceratitis capitata wied. M.Sc . Thesis, Fac. Agric Univ., Cario Egypt, 133.
Barin.BN, taragovska .A \& Franz .G (2006) Origin of Mediterranean Fruit fly (Ceratitis capitata) (wied), outbreak determined by DNA analysis. African Entomology 14, 205-209.

Buonocore , E., Colombo, A , Campe , G.\& Nucifora . A. (1999): Symptoms of damage caused by on Ceratitis capitata clusters of "Italia grapes "Informatore Fitopatologico 49,56-60.

Castro (1982) : Medfly : what happens in calforia Informatore Fitopatologico 32,10-13.

Dhouibi, M . H. and Fellah , H. (1997): Use of host marking pheromone in the control of the fruit fly Ceratitis capitata Wied (Diptera:Tephritidae). Bulletin-OILB/SROP . 20, 156-167.

El Ghawabi,A. (1928) : The Mediterranean Fruit fly. Agric. New Ann Series, Min.Agric.Cario, Egypt. 111-136.

El-Gendy, I. R. I. (2002): Studies on Peach fruit fly, Bactrocera zonata (Saund.) at El-Beheira Governorate. M. Sc. Thesis, Fac. Agric., Alexandria University. 127pp.

El-Hakim,A.M and Awad,A.I (1987):Studies on the Mediterranean Fruit fly dark inheritance : Biological and ecological factors. In: An Economopoulos (Ed) fruit flies Elsevier Science Publishers, Amsterdam, p. $125-133$.

Elhanan , S. and Roessler ,Y. (1992): Centrally organized control of Mediterranean fruit fly Ceratitis capitata in citrus groves, orchareds and vineyards (in Israel) Hassadeh. 72,873-875.

El-Mahdy, S, M (2009): Ecological and biological studies on peach fruit fly, B. zonata (Saunders) in qalubyia governrate. Ph.D. Thesis, Fac. Agric. Ain Shams. Univ. Egypt 265 pp.

El-Minshawy, A. M.; M. A. El-Eryan and A. I. Awad (1999): Biological and morphological studies on the guava fruit fly Bactrocera zonata (Saunders) (Diptera:Tephritidae) found recently in Egypt. $8^{\text {th }}$ Nat. Conf. Pests \& Dis of Veg. \& Fruits in Ismailia, Egypt : 71-82.

Gupta, D.; A. K . Verma and O. P. Bhalla (1990): Population of fruit flies (Dacus zonatus and D. dorsalis) infesting fruit crops in north Western Himalayan region. Indian. J. Agric. Sci.,60 (7): 471474.

Hashem, A. G.; M.S. A. Mohamed and M. F. El-Wakkad (2001): Diversity and abundance of Mediterranean and peach fruit flies (Diptera:Tephritidae) in different horticultural orchards. Egyptian J. Appl. Sci.; 16 (2): 303-314.

Hashem, G. A., Harris, E. J. and Saafan, M. H. (1987): Efficiency of different types of lure traps for detecting and monitoring the Mediterranean fruit fly, Ceratitis capitata (Wied.) in Egypt. Zagazig J. Agric. Res.; 14 (1): 953-970. 
Ishtiaq, A.; U. Farman and A. K. Shah (1999): Efficacy of various insecticides and trap highest in methyl eugenol baited traps against fruit flies (Bactrocera spp.). Sarhad J. Agric.; 15 (6): 589-594.

Kawashita , T .; G . B. J .P. Rajapakse and K. Tsuruta (2004): Population surveys of Bactrocera fruit flies by lure trap in Sri Lanka. Research Bulletin of the Plant Protection Service Japan, 40 (8): 83-87.

Khalaf, M.Z. , Hassan, B.H, Shbar, A.K, Naher, F.H, Salman,A.H, Jabo,N.F. (2011) : Current status of population Density of Mediterranean Fruit fly (Ceratitis capitata) in Fruit orchards in Central Iraq. Jo,311urnal of Agricultural Science and Technology A :773-777.

Khalid, M. and Mishkatullah, S. (2007): Population dynamics of three species of genus Bactrocera (Diptera: Tephritidae: Dacinae) in BARI, Chakwal. Punjab Pakistan Journal of Zoology, 39(2): 123-126.

Khan, M. A.; A. Muhammad and K. Abdul (2003): Population of fruit fly species trapped by methyl euginol and cue lure versus infestation in guava orchards. Pakistan Entomologist, 25 (1): 63-67.

Khan, M. A.; A. Muhammad; K. Abdul and A. Amjad (2002): Effect of pheromone traps on the population capture of fruit fly species and their infestation in mango orchards at Multan. Pakistan Entomologist; $24(2): 153-157$.

Liquido ,N.J. ;Shinoda , L.A. and. Cunningham, R.T.(1991): Host plants of the Mediterranean fruit fly Ceratitis capitata (Wied.) Monograph of the Etomol. Soc .Am. Publication No.77.

Mohamed, A. M. (2002): Seasonal abundance of the peach fruit fly, Bactrocera zonata (Saunders) with relation to prevailing weather factors in Upper Egypt. Assuit J. Agric. Sci.; 33 (2), 195-207.

Mohamed, M. A. (1993): Biological and ecological factors affecting the population dynamics of Mediterranean Fruit fly, Ceratitis capitata in Upper Egypt. Assuit Univ ., 205pp.

Rajitha, A. R. and V. Shashidhar (2006a) : Monitoring of fruit flies (Diptera: Tephritidae) in guava orchard at Dharwad , Karnataka Journal of Agricultural Sciences ; 19(1): 45-49.
Rajitha, A. R. and V. Shashidhar (2006b): Investigations on the population dynamics of fruit flies in mango orchard at Dharwad. Karnataka. Ibid; 19(1): 134 137.

Roditakis, E., Tsagkarakou A. and Roditakis N.E. (2008): Extensive damage on white variety table grapes by the Mediterranean fruit fly Ceratitis capitata (Wiedemann) in Crete. OEPPLEPPO Bulletin, 38: 216-219.

Saafan, M.H. (2005a): Field evaluation of some attractants for attracting the adults of Mediterranean fruit fly, Ceratitis capitata and peach fruit fly, Bactrocera zonata (Saunders), in mango orchards. Ibid; 83(3): 1107- 1119

Saafan, M. H. (1986): Studies on the Mediterranean fruit fly Ceratitis capitata Wied. With emphasis on sterile male techinques (SIT) .Ph. D. Thesis, Fac., Cairo Univ .Egypt.88pp

Saafan, M. H. (2000): Field evaluation of some attractants for attracting the adults of Mediterranean fruit fly Ceratitis capitata (Wied.) Egypt. J. Agric. Res., 78 (1): 97-107.

Saafan, M. H. (2005b). Field evaluation of some attractants for attracting the adults of Mediterranean fruit fly, Ceratitis capitata (Wiedemann), and peach fruit fly, Bactrocera zonata (Saunders), in citrus orchards. Ibid; 83(3):1141- 1156.

SAS Institute (1988): SAS/STAT User`s Guide, Ver. 6.03. SAS Institute Inc.,Cary,North Carolina.

Swart, P.L., Branes, B.N. and Myburgh ,A.C. (1976):Pests of table grapes in the Western Cape. Deciduous Fruit Grower.26, 169-172.

White, I. M. and M. M. Elson- Harris (1994): Fruit flies of economic significant; their identification and bionomics. Wallingford, UK :CAB International and Aciar, 601pp.

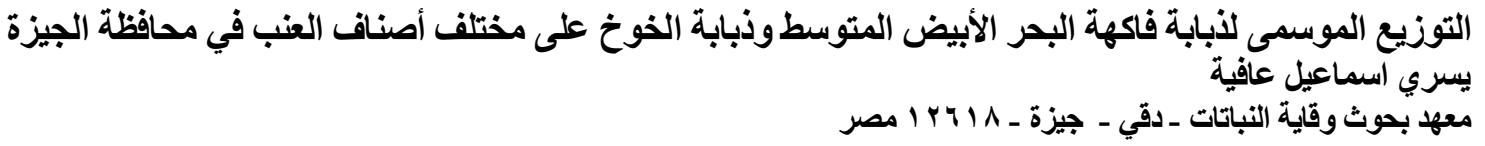

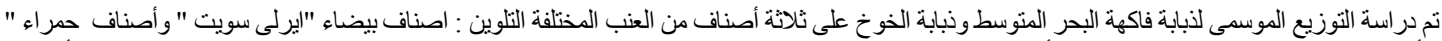

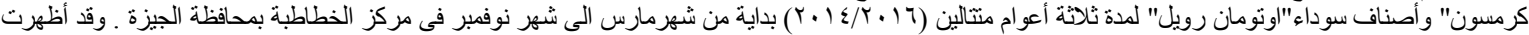

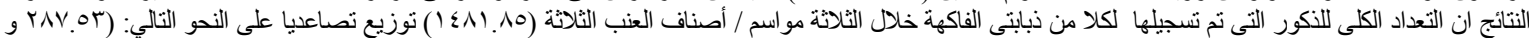

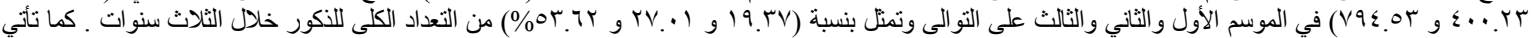

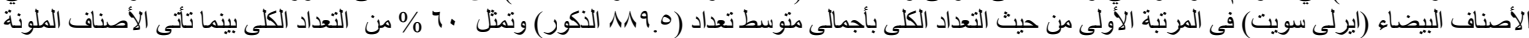

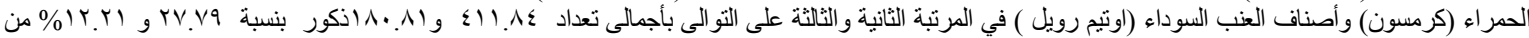

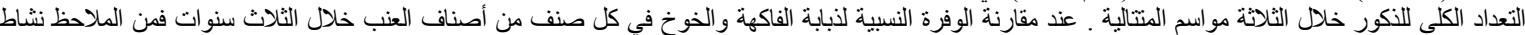

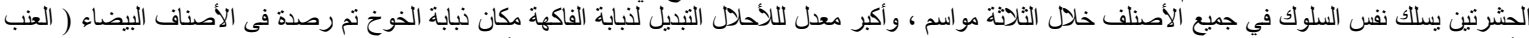

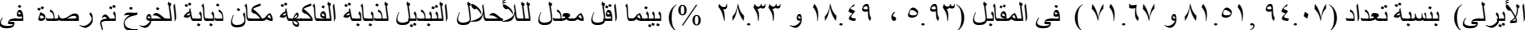

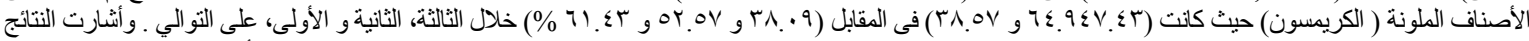

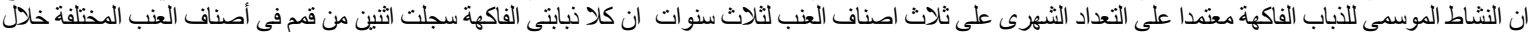

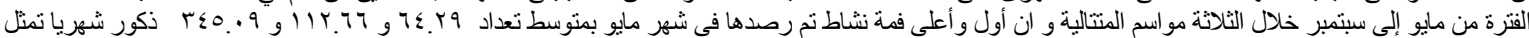

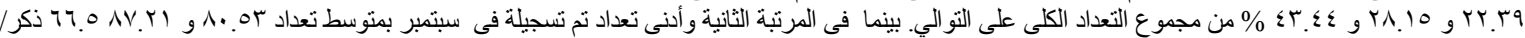

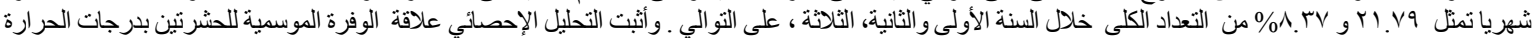

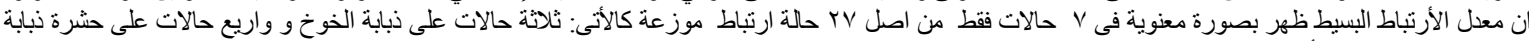

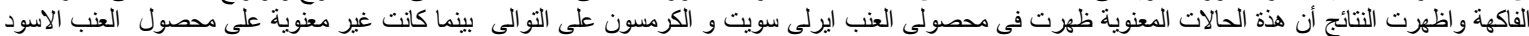

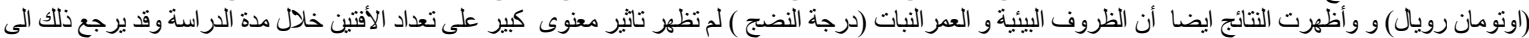

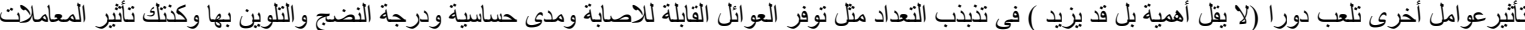

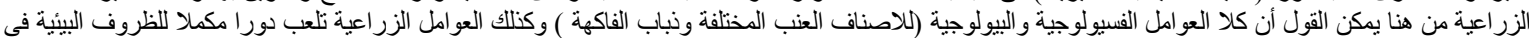
تو اجد الأفتنن على اصناف العنب المختلفة فى محافحة الجيزة. 